https://doi.org/10.31713/m1017

\title{
OPTIMIZATION OF ENERGY EFFICIENCY OF A HEAT RECUPERATOR ON THE BASIS OF UNDERGROUND COAL GASIFICATION
}

\author{
Falshtynskyi V.S.
}

Dnipro University of Technology, Candidate of Technical Science, Associate Professor, Associate Professor at the Department of

Mining Engineering and Education, Dnipro, Ukraine

\section{Saik P.B.}

Dnipro University of Technology, Candidate of Technical Science, Associate Professor, Associate Professor at the Department of Mining Engineering and Education, Dnipro, Ukraine

\section{Dychkovskyi R.O.}

Dnipro University of Technology, Doctor of Technical Science, Professor, Deputy Vice-rector for Scientific Affairs, Dnipro, Ukraine

\section{Lozynskyi V.H.}

Dnipro University of Technology, Candidate of Technical Science, Associate Professor, Associate Professor at the Department of Mining Engineering and Education, Dnipro, Ukraine

\begin{abstract}
Mining of the off-balanced and balanced reserves of mines, being under closure or completing their operation, required the implementation of mobile, complex, and environmentally friendly development technologies based on the processes of well underground coal gasification (WUCG) that unites mining of coal and its energy-chemical use. Environmental friendliness of the WUCG process is possible due to its controllability, hermeticity of the underground gas generator, and complex use of cogeneration technologies in the closed cycle of purification and processing of gasification products. The set engineering tasks were performed using analytical studies, bench studies and field studies. Efficiency of thermal energy generation were studies using rocks enclosing the underground gasifier and generator gases. These sources being the basic heat generating segments of energy chemical complex for coal gasification being formed at the territories of operating coal mines or mines at the stage of their closure. Prospects of coal gasification and thermal energy generation using rock disposals of coal mines have been estimated.
\end{abstract}

\section{Introduction}

The well underground coal gasification based mining of coal seams requires increased efficiency of the technology $[1,2]$. Those efficiency-increasing methods include the introduction of multiple- 
loop recuperators of heat energy of the "tube in tube" type with a liquid carrier of sufficient heat capacity into the rocks, enclosing the underground gas generator. That provides the possibility to remove residual heat from the rock mass during coal seam gasification and after the process completion as well as to increase the efficiency of underground coal gasification process and economic probability to gasify the coal seams of substandard thickness [3-5].

If such method is implemented, one should select the mines with a completed operating period and with substandard, overworked or underworked reserves of solid fuel [6,7]. The underground gas generator is prepared under the mine conditions with drilling of a stowing well in the seam roof, horizontal production wells throughout the seam, linkage between them, seam ignition, blow supply, coal gasification, syngas obtaining, and stowing of the deformed roof rocks and burned-out space [8-11].

Formation and functionality of the transition and reduction zones depend on the controllability and directionality of the oxidation reactions within the oxidation zones, which forms a temperature capsule in time and space around the reaction channel taking into account the fire face advance, gas generator hermeticity, and heatcapacity, thermal and temperature parameters of the rocks $[12,13]$. In terms of the reduction zone, thermochemical reactions are accompanied with the absorption of heat generated in the oxidation zone [14-16]. In terms of balanced state of the zones, compensation of endothermal effect of carbon reaction with $\mathrm{CO}_{2}$ and $\mathrm{H}_{2} \mathrm{O}$ occurs at the expense of thermal capacity of the rocks, effecting the kinetics of the reduction zone reaction in the obtaining of fuel components of a generator gas $\left(\mathrm{CO}, \mathrm{CH}_{4}, \mathrm{H}_{2}\right.$ and others) [17-19].

\section{Methodology}

In this section the calculation of heat capacity of the loop-based heat recuperation of the rocks enclosing the underground gas generator are shown.

Use the formula to determined the convection heat exchange from the tube wall to a heat carrier 


$$
N u=0,021 \cdot \mathrm{Re}^{0,8} \cdot P_{r w}^{0,43} \cdot\left(\frac{P_{r w}}{P_{r c}}\right)^{0,25},
$$

where $N u$ is Nusselt number, Re is Reynolds number; $P_{r w}$ is Prandtl number in terms of the corresponding heat carrier temperature; and $P_{r c}$ is Prandtl number in terms of the corresponding tube wall temperature.

Determine Reynolds number from the formula

$$
\operatorname{Re}=\frac{v \cdot d}{v_{w}}
$$

where $v_{w}$ is coefficient of viscosity $\left(\mathrm{m}^{2} / \mathrm{s}\right)$.

Coefficient of heat capacity is found from the equation, $\mathrm{W} / \mathrm{m}^{2} \cdot{ }^{\circ} \mathrm{C}$

$$
\alpha_{2}=\frac{\lambda_{w} \cdot N u}{d},
$$

where $\lambda_{w}$ is coefficient of heat conductivity $\left(\mathrm{W} / \mathrm{m} \cdot{ }^{\circ} \mathrm{C}\right)$.

Coefficient of heat transfer from the hot rocks to a heat carrier is as follows, $\mathrm{W} / \mathrm{m} \cdot{ }^{\circ} \mathrm{C}$

$$
k_{l}=\frac{1}{\frac{11}{\alpha_{2} \cdot d_{2}}+\frac{1}{2 \cdot \lambda_{c}} \cdot \ln \left(\frac{d_{2}}{d_{1}}\right)},
$$

where $k_{l}$ is heat amount transferred from the rocks to a heat carrier through $11 \mathrm{l}$. of a pipe in terms of the temperature difference by $1^{\circ} \mathrm{C} ; \lambda_{c}$ is heat conductivity of the water wall material, $\mathrm{W} / \mathrm{m} \cdot{ }^{\circ} \mathrm{C}$.

The amount of heat a heat carrier obtains is as follows

$$
Q_{w}=G \cdot C_{p} \cdot \Delta t
$$

where $G$ is heat carrier consumption that depends on the internal diameter of a collector and heat carrier velocity in it; $C_{p}$ is heat capacity of a heat carrier; and $\Delta t$ is difference of temperatures while heat transferring of $11 \mathrm{~m}$. of a pipe.

$$
\Delta t=t_{2}-t_{1}
$$

where $t_{2}$ is temperature of the hot rocks, ${ }^{\circ} \mathrm{C} ; t_{1}$ is temperature of a heat carrier, ${ }^{\circ} \mathrm{C}$.

\section{Results and Discussion}


Technological scheme of heat recuperation of the generatorenclosing rocks as well as the heat recuperator design should take into consideration the peculiarities of thermochemical processes occurring in the reaction channel. Developed at the Department of Underground Mining and Education of the Dnipro University of Technology, the preparation method and system of the coal seam development in terms of mines (wings, walls) during WUCG with the utilization of gas generator energy heat (Fig. 1) as well as the technological scheme and the recuperator structure (Fig. 2) meet the abovementioned requirements.

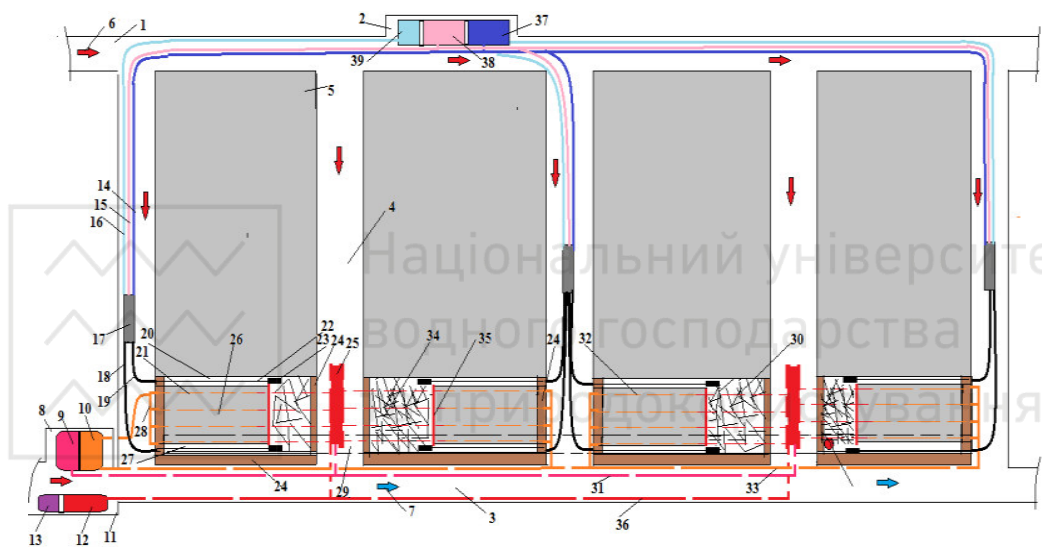

Fig. 1. Scheme of coal seam preparation and development under the mine (block) conditions in terms of WUCG is level-by-level; mining system is longwall mining to the dip; subsystem of the coal seam development being gasified is along the strike: $1-$ main haulage roadway; 2 - compressor chamber; 3 -drainage roadway; 4 -ventilation pathway; 5 -extraction pillar; 6 -fresh ventilation flow; 7 - outlet ventilation flow; 8 - heat carrier chamber; 9 - cooling unit of a pump plant of a heat carrier; $10-$ supplying unit of a pump plant of a heat carrier; 11 - heat turbine chamber; $12-$ turbine unit; 13 - power generator; 14 - rubber air pipeline; 15 - rubber pipeline for the overheated steam; 16 - rubber oxygen pipeline; 17 - site blow mixer (SBM); 18 flexible metal pipeline for the gas outlet well $27 ; 19$ - flexible metal pipeline; 20 blow well; 21 - heat recuperator pipeline with a cold heat carrier; 22 - flexible blow pipeline; 23 -perforated nozzle; 24 -heatproof phosphogypsum stopping; $25-$ assembled heat recuperator with the carrier and steam separation; 26 -coal pillar being gasified; 28 - network separation of a carrier; 29 - berm of a drainage roadway in the seam floor; 30, 34 - burned-out space; 31 - pipeline to cool down a heat carrier; 32 , 33 - pipelines for a heat carrier; 34 - burned-out space; 35 - fire face of the reaction channel; 36 -steam pipeline; 37 -compressor; 38 - steam generator; 39-oxygen generator 

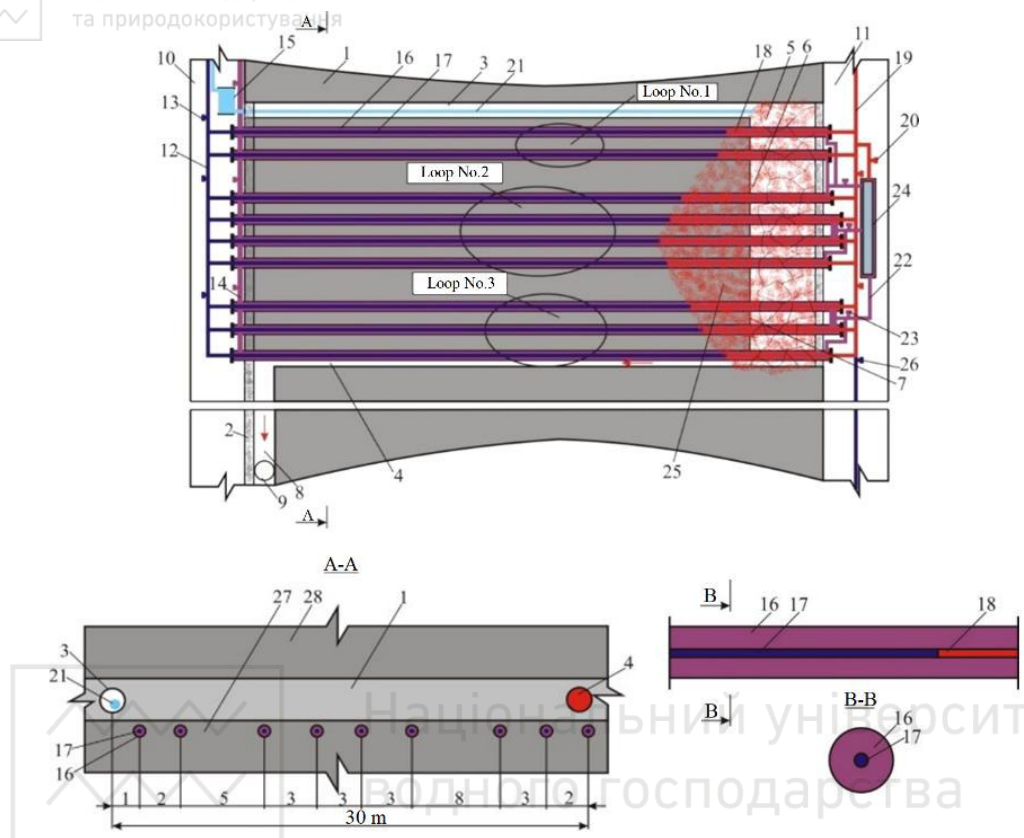

Fig. 2. Technological scheme of a three-loop recuperator of the underground gas generator heat, A-A section, and structure of a "tube in tube" recuperator with the location of Б heat carriers: 1 -coal seam; 2 -thermal insulating stopping; 3 recuperation element; 4 -gas outlet horizontal well; 5-burned-out space; $6-$ reaction channel of a gas generator; 7 - fire face; 8 - berm of the air-supplying drift; 9 - vertical gas outlet well; 10 - air-supplying drift; 11 - heat-removing drift; 12 pipeline with a cold heat carrier (water); 13 - controlled water distribution valves; 14 - pipeline with a heat carrier (solution of liquid alkaline metals $\mathrm{Na}$ or glycol); 15 - drum for a flexible air-supplying pipeline $(d=32 \mathrm{~mm}) ; 16$ - pipeline $(\mathrm{d}=75-$ $100 \mathrm{~mm})$ with a heat carrier (Na or glycol); 17 - pipeline $(d=50-75 \mathrm{~mm})$ with a heat carrier, water; 18 - pipeline with steam; 19 - steam pipeline $(d=100-120 \mathrm{~mm})$; 20 - controlled steam distribution valves; 21 - flexible air-supplying pipeline; $22-$ section of the pipeline with a boiling heat carrier $\left(\mathrm{Na}\right.$ or glycol, $T_{k}=260-620^{\circ} \mathrm{C}$ ); 23 - controlled valves for the boiling heat carrier distribution ( $\mathrm{Na}$ or glycol); $24-$ boiler-recuperator of heat; 25 - support zone; 26 - controlled pipelines distributing valves; 27 - roof of the coal seam being gasified; 28 - floor of the coal seam being gasified

According to the proposed measured, the procedure is as follows. Horizontal wells are drilled in the seam floor; three loops of the "tube in tube" system with heat carriers of different thermal and physical properties are mounted into the wells throughout the 
reaction channel according to the temperature distribution. That will make it possible to remove residual heat effectively and quickly over the whole area of temperature spread in both gas generator and its enclosing rocks during the gasification process and after the gasification completion while finishing the operations with the obtaining of heat and electric energy within the underground gasification area [0]. Fig. 2 shows the developed technological scheme of a three-loop recuperator of the underground gas generator in terms of A-A section and the structure of a "tube in tube" recuperator with the location of heat carriers.

According to the calculations, 9 inclined (horizontal) wells are drilled throughout the length of the reaction channel (6) in the seam floor at the distance of $0.15-0.2 \mathrm{~m}$ from the coal seam from the drift (10) to the drift (11) to the extracti on pillar dip. In those wells, the pipeline (16) $(d=75-100 \mathrm{~mm})$ of heat recuperator with a heat carrier (Na or glycol) is mounted; the pipeline (17) of $d=50-75 \mathrm{~mm}$, which heat carrier is water, is inserted into the pipeline (16) of $d=50-75 \mathrm{~mm}$. On the drift side $(10)$, the pipelines $(12,14)$ (heat carriers: water, $\mathrm{Na}$ or glycol) with the automatically controlled valves of heat carrier distribution (13) are laid towards the pipelines (16) and (17) from the pumps. Within the drift (11), the pipeline (17) of the heat recuperator is connected with the steam pipeline (19), $d=100-120 \mathrm{~mm}$; the pipeline (16) is connected with the boiler-recuperator of heat (24) from the boiling heat carrier ( $\mathrm{Na}$ or glycol). The steam pipeline (19) is mounted towards the steam power plant to generate thermal and electric energy.

The analysis of the carried-out experimental studies within the gasified share of the underground gas generator has shown that the rock heating up to $50{ }^{\circ} \mathrm{C}$ accounts for $62.8 \%$, up to $100{ }^{\circ} \mathrm{C}-39 \%$, up to $400{ }^{\circ} \mathrm{C}-17.5 \%$, and up to $900{ }^{\circ} \mathrm{C}-6.9 \%$. In its turn, the analysis of stand studies within the mass of temperature distribution has demonstrated that heating up to $50{ }^{\circ} \mathrm{C}$ accounts for $36.2 \%$; up to $400^{\circ} \mathrm{C}$ - $11.4 \%$, and up to $900{ }^{\circ} \mathrm{C}-4.4 \%$, and distribution of temperatures in terms of WUCG along the rock stratification is by 1.4 times less than perpendicularly to the stratification $[0,0]$. The studies $[0,0]$ have helped define that the development and stabilization of a thermochemical process of the coal seam processing (1) in the reaction channel (6) is accompanied with the temperature distribution with the formation of a temperature field around it within the rocks (Fig. 3, 4). 


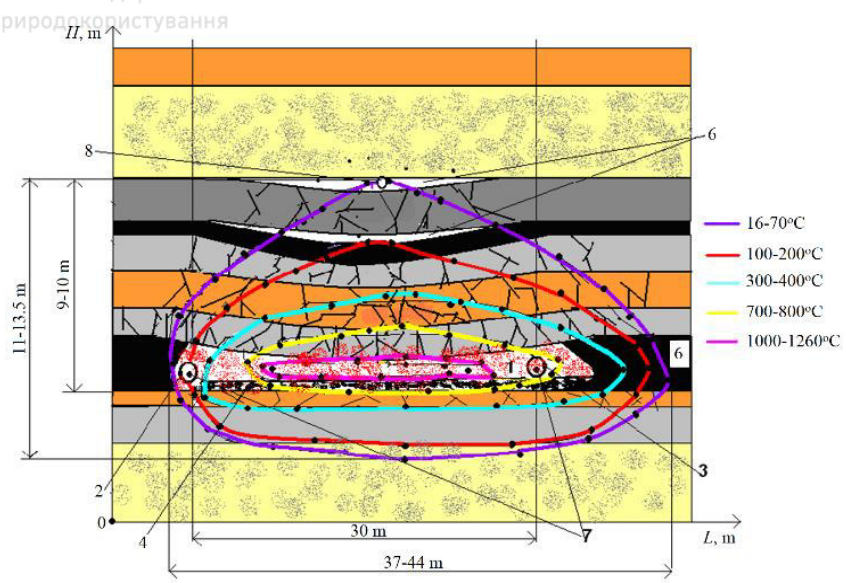

Fig. 3. Parameters of the rock coal mass heating across the stratification: 1reaction channel of the underground gas generator; 2 -blow inclined-horizontal well; 3 -gas outlet inclined-horizontal well; 4 -ash residue; 5 - cavity of the roof rocks stratification; 6 - coal seam; 7 - flexible pipeline; 8 - stowing pipeline

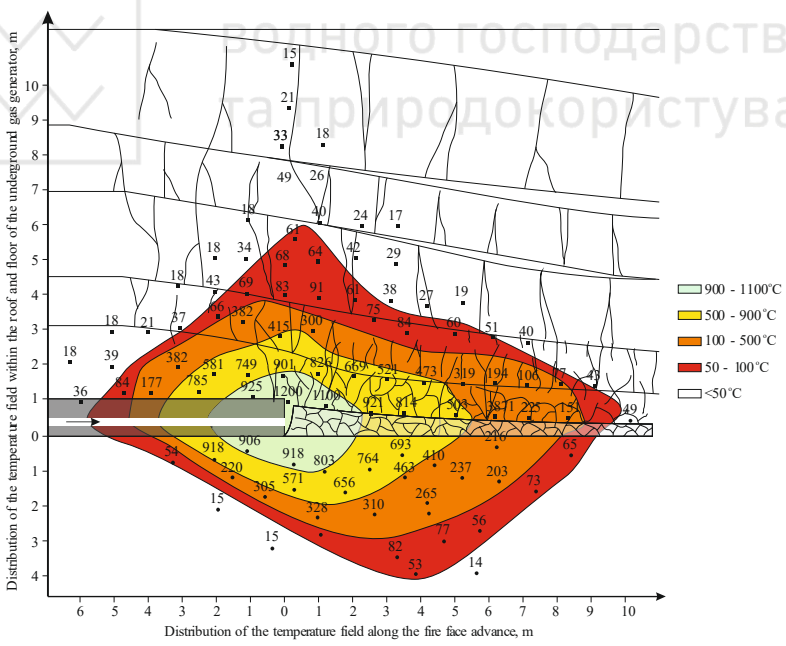

Fig. 4. Parameters of the temperature field distribution within the rocks while coal seam gasifying

According to the analysis of the experimental underground gas generators as well as laboratory, and stand studies, a graph of rock heating within the support zone within the affected area of the 
underground gas generator has been developed (Fig. 5). Taking into consideration a heat flow, average coefficient of heat transfer from gas to rocks has been identified - $K_{n}=78.2 \mathrm{~kJ} / \mathrm{m}^{2}$ hour ${ }^{\circ} \mathrm{C}$. If we consider Joule Thomson effect of the rock mass enclosing the underground gas generator, then the coefficient will be $K_{n}=43.5 \mathrm{~kJ} /$ hour ${ }^{\circ} \mathrm{C}$. Table 1 shows the obtained profiles of temperatures and pressures in the fire channel of the underground gas generator depending on its length.

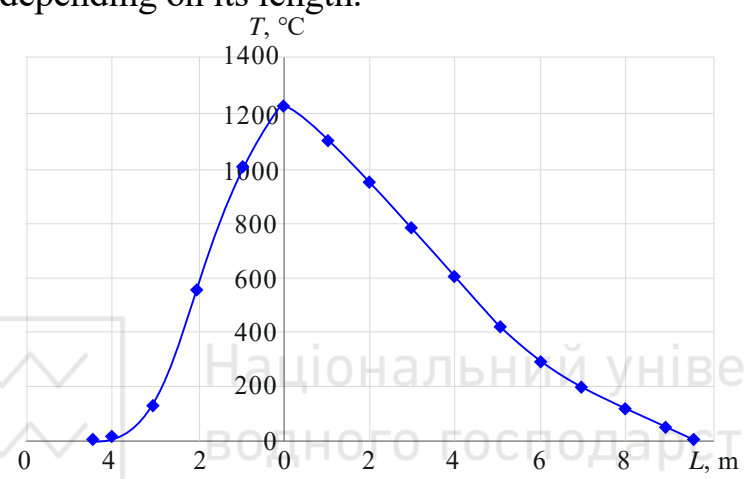

Fig. 5. Rock heating within the support zone and the affected area of the underground gas generator

Table 1

Calculation profile of the temperatures and pressures along the fire channel length

\begin{tabular}{c|c|c|c|c}
\hline \multirow{2}{*}{$\begin{array}{c}\text { Length of the } \\
\text { fire channel, } \mathrm{m}\end{array}$} & \multicolumn{3}{|c|}{$\begin{array}{c}\text { Temperature profile throughout } \\
\text { the fire channel, }{ }^{\circ} \mathrm{C}\end{array}$} & $\begin{array}{c}\text { Pressure throughout } \\
\text { the fire channel, MPa }\end{array}$ \\
\cline { 2 - 4 } & $25 \mathrm{~m}$ & $30 \mathrm{~m}$ & $60 \mathrm{~m}$ & 0.60 \\
\hline 0 & 200 & 200 & 200 & 0.58 \\
\hline 5 & 565 & 518 & 505 & 0.57 \\
\hline 10 & 882 & 740 & 610 & 0.54 \\
\hline 15 & 1180 & 809 & 770 & 0.59 \\
\hline 20 & 864 & 1240 & 967 & 0.60 \\
\hline 25 & 697 & 911 & 1190 & 0.60 \\
\hline 30 & - & 589 & 1007 & 0.54 \\
\hline 35 & - & - & 926 & 0.54 \\
\hline 40 & - & - & 819 & 0.57 \\
\hline 45 & - & - & 755 & 0.57 \\
\hline 50 & - & - & 641 & 0.58 \\
\hline 55 & - & - & 537 & 0.58 \\
\hline 60 & - & - & 459 & \\
\hline
\end{tabular}


The experiments have made is possible to specify that the temperature value of the coal seam gasification varies throughout the reaction channel (6) length. The temperature maximums (1100-1300 ${ }^{\circ} \mathrm{C}$ ) are observed with the transition of the oxidation zone into the reduction one (Fig. 6).

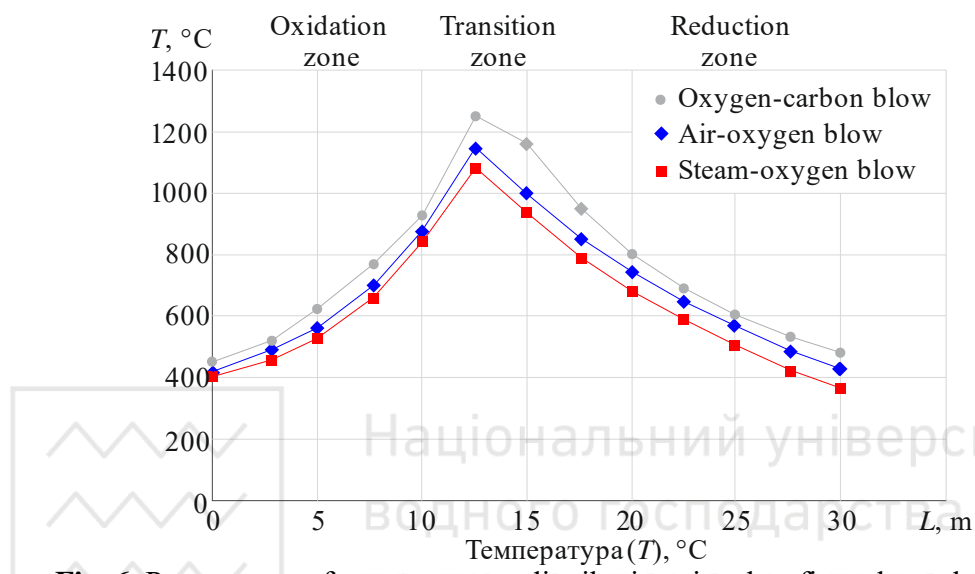

Fig. 6. Parameters of temperature distribution in the fire channel of the underground gas generator

Thus, the rocks above the fire face are subject to different thermal loading. The same situation is observed within the burned-out space. Along with the coal seam gasification and fire face advance (7), roof rocks (27) are collapsing under the effect of rock pressure and rock temperatures with the formation of a burned-out space of the gas generator. Heat and gasification products leave the gas generator through the well (4) and vertical gas outlet well (9); and a heat share (up to $30-49 \%$ ) is accumulated within the rocks enclosing the gas generator (see Fig. 2.).

The heat accumulated from the rocks within the support zone (25), fire face (7), burned-out space (5), and seam floor (28) is taken by the heat "tube in tube" recuperator according to the loop scheme and parameters of the temperature field formation in the underground gas generator involving a heat carrier with different thermophysical 
properties, which provides efficiency and stability of the heat recuperation functioning irrespective of changes in heat and material balance of the processes as well as geomechanical parameters of the rock thickness enclosing the gas generator $[0,0]$.

The external pipeline (16) with a heat carrier (solutions of liquid metals $\mathrm{Na}, \mathrm{Na}-\mathrm{K}$ or glycol) with boiling temperature $T_{k}=260-620{ }^{\circ} \mathrm{C}$ transfers the heat obtained from the gas generator rocks to the external pipeline into a heat carrier (water) at the velocity of $0.1-$ $0.15 \mathrm{~m} / \mathrm{s}$. Having entered the zone of temperatures being more than $100{ }^{\circ} \mathrm{C}$ in the steam pipeline (18), water transforms into the overheated steam (loop $1-T_{1}=160-190^{\circ} \mathrm{C}$ with $P_{1}=0.3-0.8 \mathrm{MPa}$ pressure; loop $2-T_{2}=250-340{ }^{\circ} \mathrm{C}$ with $P_{2}=1.5-2.7$

$\mathrm{MPa}$ pressure; and loop $3-T_{3}=180-260^{\circ} \mathrm{C}$ with $P_{3}=1.1-2.2 \mathrm{MPa}$ pressure) and sent further through the steam pipeline (19), equipped with the controlled steam distribution valves (20), onto the steam turbine with $T=230-280^{\circ} \mathrm{C}$ steam parameters with $P=1.8-2.3 \mathrm{MPa}$ pressure. In terms of the external heat carrier boiling with the section (22) of the pipeline (16) that can occur depending on the temperature indices in the underground gas generator within loop 2, a boiling heat carrier is discharged into the external case of the boiler-recuperator, where the internal case contains water, which transforms into steam under the temperature action and, being of $T=150-260{ }^{\circ} \mathrm{C}$ temperature and $P=0.8-1.8 \mathrm{MPa}$ pressure, goes into the steam pipeline (23) with the help of the controlled valves.

The heat balance equation helps determine the heat carrier velocity in the pipeline for different technological parameters: pipe diameters, heat carrier temperature in the collector pipeline at the outlet from the combustion zone, value of the combustion zone $[0,0]$.

The proposed method will help do the following: remove the residual heat effectively and rapidly throughout the whole area of temperature spread within the underground gas generator during the coal seam gasification as well as on the completion of the 
gasification process while finishing the operations, obtaining heat and electric energy within the underground gasification area; conduct effectively the coal seam gasification under conditions of technogenic disturbance of the mass; and provide economic expediency of the gasification of low-thickness coal seams [0].

Solution of those problems requires a complex approach, which is completely in compliance with the concept of the development of WUCG technological schemes under the mine conditions elaborated in the Dnipro University of Technology at the Department of Underground Mining (Fig. 7).
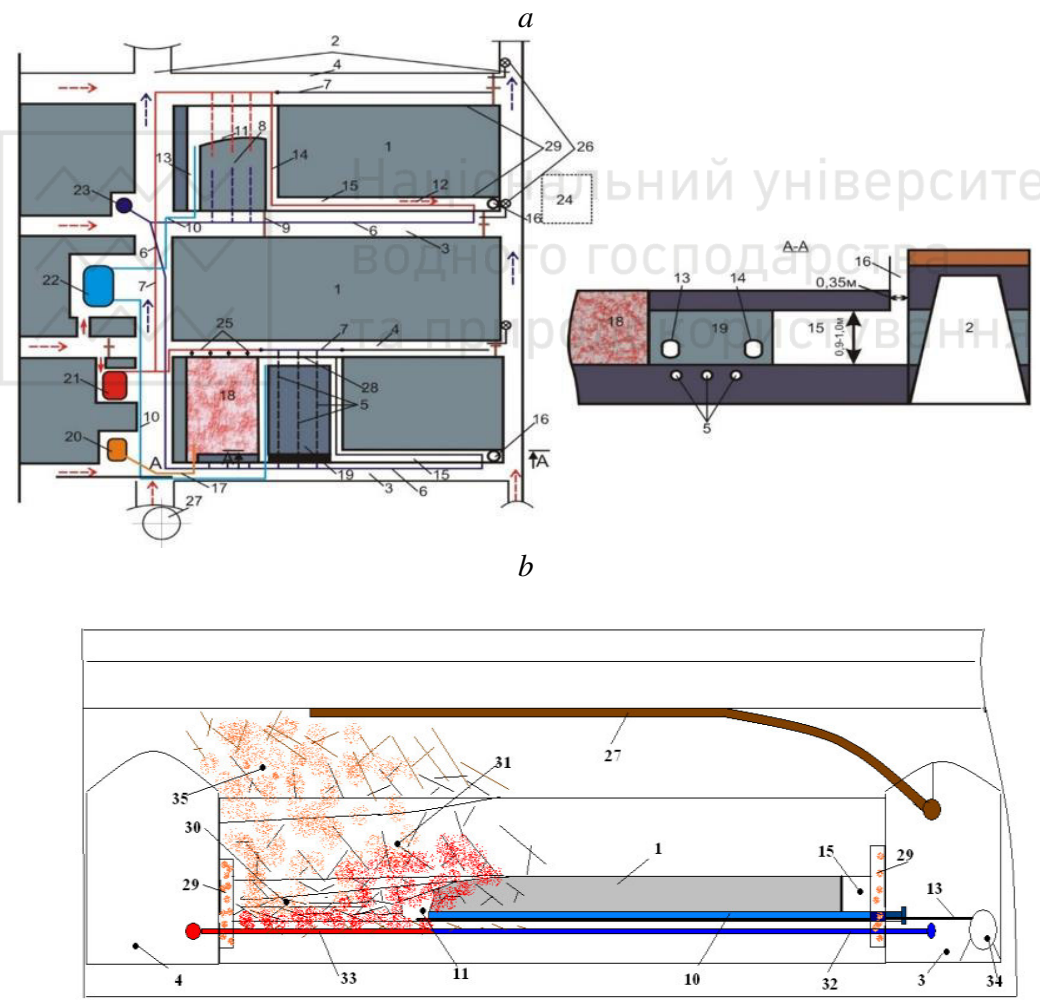


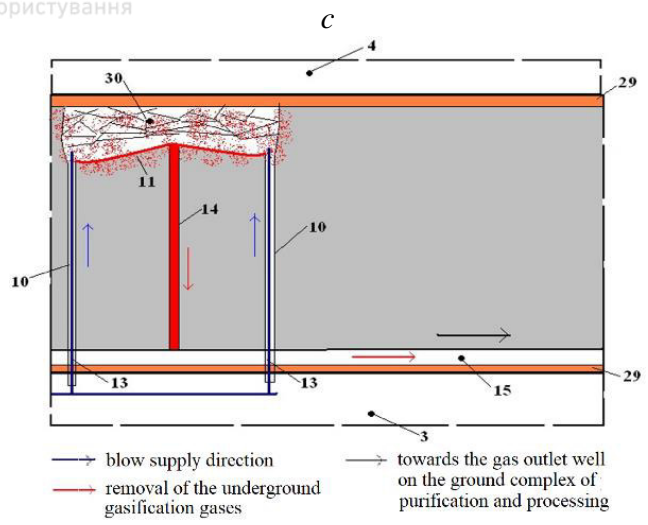

Fig. 7. Technological scheme of a mobile-modular energochemical enterprise on the basis of an operating mine while mining unbalanced coal reserves: $(a)$ - top view; $(b)$ - cross section of a gas generator; $(c)$ - gasification of the extraction pillar by jointed gas generators ( $L_{2}=$ length of reaction channels being 30,20 , and $25 \mathrm{~m}$ ); 1 -extraction pillars outlined along the strike and to the dip by the development workings; 2 - air-supplying pathway; 3 - blow drift; 4 - air drift; 5 -wells with the pipes mounted inside to supply heat carrier into the active zone; 6 -main pipeline with the heat carrier; 7 -main pipeline; 8 -sites of workings neighbouring the operating gas generator; 9 -sealed stoppings; 10 -pipeline from the compressor complex to the blow well; 11 - fire channel; 12 -gasification products; 13 - blow horizontal well; 14 - horizontal gas outlet well; 15 - berm of the blow drift; $16-$ vertical gas outlet well connected with the ground complex; 17 - perforated stowing pipeline; 18 - sites of the underground workings of the extinguishing gas generator; 19 - module-gas generator; 20-stowing complex; 21 - heat turbines; $22-$ compressor complex; 23 - active zone of the heat carrier; 24 - ground complex; 25 drift pipeline towards the turbine; 26 - pipeline of the ventilation pathway; $27-$ stowing well; 28 - berm of the air drift; 29 - phosphogypsum boundary line; 30 burned-out space; 31 - deformed roof rocks; 32 - tube recuperator with a cold heat carrier; 33 - tube recuperator with an overheated heat carrier (steam); 34 - hoisting unit for the flexible blow pipeline; 35 - stowing injection mass

Preparation of the underground gas generator involves cutting of three extraction pillars along the strike within the mine field with the modular gas generator mining to the rise (to the dip) with the utilization of heat energy of the gasification products and hot rocks, enclosing the gas generator, under the mine conditions.

The mine field area is divided into three pillars (1) outlined along the strike and to the dip by the development workings, air-supplying pathways (2), blow (3) and air (4) drifts. The extraction pillar length 
is $L_{\Pi \mathrm{p}}=200-400 \mathrm{~m}$; its depth to the dip (rise) is $L_{\Pi(\mathrm{B})}=100 \mathrm{~m}$. Chambers of heat turbines (21) and compressor complex (22) are formed within the opposite part of the extraction pillar (Fig, 7).

To remove heat from the gasification products and hot rocks, wells are drilled in the seam floor (vertical and horizontal wells along the coal seam); then the "tube in tube" recuperators (5) with different design features and heat carriers are installed in them. That will favour uniform heat removal from the rocks taking into account nonuniformity of temperature distribution in the gas generator. Heat carrier supply into the active zone $(6,23)$ is performed from the blow drift (3) where the main pipeline with a heat carrier (6) is located.

Passing through the pipes (5), a heat carrier transforms into steam and travels under pressure along the main pipeline (7) located on the air drift (4) to the heat turbine (21) for electric power generation.

Flow velocity of the heat carrier in the pipes of a rock heat recuperator of the underground gas generator is $0.05-0.1 \mathrm{~m} / \mathrm{s}$ depending on the stage of gas generator operation, heat capacity, heat conductivity of the floor rocks, and temperature of the UCG products.

Length of the modular gas generator is taken basing on the seam thickness and capacities of drilling facilities. Distance between the wells is determined depending on the seam thickness, geomechanical indices, hydrogeological conditions, and technological parameters of the underground gasification processes.

Further, the reaction zone is formed. A coal seam is ignited from the berm of the air drift (28) by means of hot coke and supply of the oxygen-enriched blow or with the help of binary charges on the connection with the blow well (10).

The advance pillar gasification is performed by supplying blow mixture from the blow drift (3) through the blow pipeline (10) from the compressor complex (22) into the blow horizontal well (13) of $290-250 \mathrm{~mm}$ diameter and further on the fire channel (11) being $l_{0.3}=20-40 \mathrm{~m}$ long. Next, along with the passing of oxidation and reduction zones, gasification products (12) travel into the horizontal gas outlet well (14) with the diameter of $290-350 \mathrm{~mm}$ and, along the blow drift berm (15) - into the vertical gas outlet well (16) connected 
with the ground complex (24) for purification and processing of gasification products for producing electric energy and chemical raw material.

Not less than two modular gas generators are under the operation. The mine field is developed in terms of a pillar, which provides safe operation of ventilation and modular gas generators.

Sites of the mine workings adjoining the operating and extinguishing gas generators $(8,18,26)$ are isolated by the sealed stoppings (9); ventilation is forced with the help of fans of local ventilation (26) with warm air outburst into the air-supplying pathway (2).

On the completion of operations, the mixture is kept to be injected into the mined-out space of a modular generator through the blow well. Stowing operations are carried out along with the fire face advancing of the modular generator by injecting a mixture into the deformed thickness of the roof rocks and into the worked-out space. During the coal seam gasification, injection of the deformed roof rocks is performed along the stowing well (27) located above the coal seam.

After the pillar gasifying, there should be the operations for gas generator extinguishing related to the stowing of the burned-out space (18). Stowing material is prepared and supplied from the stowing complex (20) with the help of the perforated pipeline (17) laid within the blow well. Residual heat of the rock mass is removed by means of tube recuperators (25) and sent onto the heat turbine in the form of water steam.

During those operations, a module-generator (19) located in other extraction pillar is put into operation; when the operations in the gasgenerator (19) are over, a gas generator in the first extraction pillar starts its operation. Tables 2 and 3 show the indices and technological parameters of the underground gasification of a gas coal seam under the mine conditions. 
Table 2

WUCG parameters in terms of different blow type

\begin{tabular}{|c|c|c|c|c|c|c|c|c|c|c|c|}
\hline \multirow[t]{2}{*}{ Blow type } & \multicolumn{3}{|c|}{$\begin{array}{c}\text { Blow composition, } \\
\% \%\end{array}$} & \multicolumn{7}{|c|}{ Composition of the outgoing gases, $\%$} & \multirow{2}{*}{$\begin{array}{c}\mathrm{Q} \\
\mathrm{MJ} / \mathrm{m}^{3}\end{array}$} \\
\hline & $\mathrm{O}_{2}$ & $\mathrm{CO}_{2}$ & steam & $\mathrm{H}_{2}$ & $\mathrm{CH}_{4}$ & $\mathrm{C}$ & $\mathrm{N}_{2}$ & $\mathrm{H}_{2} \mathrm{~S}$ & $\mathrm{CO}_{2}$ & $\mathrm{O}_{2}$ & \\
\hline $\mathrm{O}_{2} \mathrm{~N}_{2}$ & 23 & - & - & 9.1 & 6.0 & 18.4 & 55.8 & 0.35 & 9.3 & 1.2 & 5.3 \\
\hline $\mathrm{O}_{2} \mathrm{~N}_{2}$ & 66 & - & - & 18.7 & 10.2 & 30.7 & 20.4 & 0.8 & 16.0 & 3.2 & 9.5 \\
\hline $\mathrm{O}_{2} \mathrm{~N}_{2}$ & -1 & - & - & 16.5 & 12.4 & 33.8 & 20.0 & 0.7 & 14.1 & 2.5 & 9.6 \\
\hline $\mathrm{H}_{2} \mathrm{O}+\mathrm{O}_{2}$ & 23 & - & 8.0 & 8.1 & 6.1 & 21.4 & 52.5 & 0.5 & 10.0 & 1.4 & 5.8 \\
\hline \multirow{2}{*}{$\mathrm{H}_{2} \mathrm{O}+\mathrm{O}_{2}$} & 56 & - & 19.5 & 15.3 & 10.6 & 37.4 & 8.2 & 1.3 & 23.2 & 4.0 & 10.2 \\
\hline & 53 & - & 30.6 & 11.6 & 10.4 & 38.6 & 7.3 & 1.0 & 27.2 & 3.9 & 11.2 \\
\hline \multirow{3}{*}{$\mathrm{CO}_{2}+\mathrm{O}_{2}$} & 54 & 42.0 & - & 16.5 & 10.1 & 49.6 & 1.3 & 1.3 & 17.8 & 3.4 & 10.8 \\
\hline & 50 & 30.7 & - & 15.7 & 9.4 & 45.8 & 2.1 & 1.1 & 22.5 & 3.4 & 9.9 \\
\hline & 50 & 38.5 & - & 15.8 & 9.8 & 49.4 & 2.1 & 1.2 & 18.3 & 3.4 & 11.5 \\
\hline \multirow{2}{*}{$\begin{array}{l}\mathrm{CO}_{2}+\mathrm{C}_{2}+ \\
+\mathrm{H}_{2} \mathrm{O}\end{array}$} & 52 & 34.4 & 15.4 & 16.5 & 11.5 & 47.6 & 2.9 & 0.9 & 17.3 & 3.3 & 11.0 \\
\hline & 44 & 36.9 & 11.0 & 16.0 & 9.5 & 50.3 & 2.6 & 0.9 & 17.5 & 3.2 & 10.7 \\
\hline
\end{tabular}

Table 3

Technological parameters of the gasification process

\begin{tabular}{|c|c|c|c|c|c|c|}
\hline $\begin{array}{l}\text { Pressure in } \\
\text { the fire } \\
\text { channel, } \\
P, \mathrm{MPa}\end{array}$ & $\begin{array}{l}\text { Tempe- } \\
\text { rature of } \\
\text { the } \\
\text { process, } \\
T,{ }^{\circ} \mathrm{C}\end{array}$ & $\begin{array}{c}\text { Temperature } \\
\text { of gases in } \\
\text { the vertical } \\
\text { well, } \\
T_{2},{ }^{\circ} \mathrm{C}\end{array}$ & $\begin{array}{c}\text { Advance } \\
\text { rate of the } \\
\text { fire face, } \\
\mathrm{m} / \text { day }\end{array}$ & $\begin{array}{l}\text { Adherence to } \\
\text { the parity of } \\
\text { the oxidation } \\
\text { and reduction } \\
\text { zones }\end{array}$ & $\begin{array}{c}\text { Heat } \\
\text { capacity of } \\
\text { a gas } \\
\text { generator, } \\
\text { Gcal/hour }\end{array}$ & $\begin{array}{c}\text { Electric } \\
\text { capacity of a } \\
\text { gas generator, } \\
\mathrm{kW} / \text { hour }\end{array}$ \\
\hline $1.6-3.0$ & $\begin{array}{c}1050- \\
1250\end{array}$ & $350-6000$ & $0.5-2.2$ & $\begin{array}{l}0.3-0.7 \\
0.4-0.6\end{array}$ & $5-8$ & $5760-9280$ \\
\hline
\end{tabular}

Generator gas and condensate are purified and processed in terms of the surface complex with the obtaining of electric energy and chemical raw material with the immediate utilization of the residual gasification products heat.

Taking into consideration that the coefficient of efficiency of the recuperation plants is $\eta=53-62 \%$ and applying the commonly known principles of transferring the spatial power into the time power, calculation heat power of the loop-based recuperation of the rocks enclosing the underground gas generator will be $4.6-8.5 \mathrm{Gcal} /$ hour, corresponding to $5336-9860 \mathrm{~kW} /$ hour.

\section{Conclusions}

The WUCG-based energy-chemical complex is a mobile moduletype enterprise providing intense increment of productivity, quality, and diversity of the products of organic fuel gasification. It helps 
reorient dynamically and losslessly the end-product output in the form of thermal and electric power, chemical substances, and products owing to flexibility of technological parameters and taking into consideration the conditions of dynamic changes in a mining and geotechnical situation.

Profitability and efficiency of WUCG-based energy-chemical complex are obvious as we can observe the following: growing prices for oil, gas, and coal due to the costs for extraction, transportation, processing, environmental protection, and depletion of balanced reserves of energy raw material.

The calculated heat power of the loop-based rock heat recuperation will be $4.6-8.5 \mathrm{Gcal} /$ hour $(5336-9860 \mathrm{~kW} /$ hour $)$ with the efficiency of $53-62 \%$. A period of the effective operation of the recuperator is from 2.2 up to 4.6 years.

\section{References}

1. Df Maev, S., Blinderman, M.S., \& Gruber, G.P. (2018). Underground coal gasification (UCG) to products: Designs, efficiencies, and economics. Underground Coal Gasification and Combustion, 435-468. https://doi.org/10.1016/b978-0-08100313-8.00013-x

2. Wang, G.X., Wang, Z.T., Feng, B., Rudolph, V., \& Jiao, J.L. (2009). Semi-industrial tests on enhanced underground coal gasification at Zhong-LiangShan coal mine. Asia-Pacific Journal of Chemical Engineering, 4(5), 771-779. https://doi.org/10.1002/apj.337

3. Tabachenko, M. (2016). Substantiating parameters of stratification cavities formation in the roof rocks during underground coal gasification. Mining of Mineral Deposits, 10(1), 16-24. https://doi.org/10.15407/mining10.01.016

4. Khan, M. S., Zhu, Z., Huang, Q., Bai, Y., \& Sun, L. (2019). Thermal hydraulic analysis of concentric recuperator of DRAGON-V loop. Fusion $\begin{array}{llll}\text { Engineering and Design, } & 142,19 .\end{array}$ https://doi.org/10.1016/j.fusengdes.2019.04.042

5. Kim, I.H., \& No, H.C. (2011). Thermal hydraulic performance analysis of a printed circuit heat exchanger using a helium-water test loop and numerical simulations. Applied Thermal Engineering, 31(17-18), 4064-4073. https://doi.org/10.1016/j.applthermaleng.2011.08.012

6. Petlovanyi, M., Lozynskyi, V., Saik, P., \& Sai, K. (2019). Predicting the producing well stability in the place of its curving at the underground coal seams $\begin{array}{lllll}\text { gasification. E3S Web of Conferences, } 01019 . & \text { (123), } 0\end{array}$ https://doi.org/10.1051/e3sconf/201912301019

7. Kovalevska, I., Samusia, V., Kolosov, D., Snihur, V., \& Pysmenkova, T. (2020). Stability of the overworked slightly metamorphosed massif around mine working. Mining of Mineral Deposits, 14(2), 43-52. 
8. Dychkovskyi, R., Falshtynskyi, V., Lozynskyi, V., \& Saik, P. (2015). Development the concept of borehole underground coal gasification technology in Ukraine. New Developments in Mining Engineering 2015: Theoretical and Practical Solutions of Mineral Resources Mining, 91-95. https://doi.org/10.1201/b19901-18

9. Lozynskyi, V.G., Dychkovskyi, R.O., Falshtynskyi, V.S., Saik, P.B., \& Malanchuk Ye.Z. (2015). Experimental study of the influence of crossing the disjunctive geological fault on thermal regime of underground gasifier. Naukovyi Visnyk Natsionalnoho Hirnychoho Universytetu, (5), 21-29.

10. Saik, P., Falshtynskyi, V., Dychkovskyi, R., \& Lozynskyi, V. (2015). Revisiting the preservation of uniformity advance of combustible face. Mining of Mineral Deposits, 9(4), 487-492. https://doi.org/10.15407/mining09.04.487

11. Saik, P.B., Dychkovskyi, R.O., Lozynskyi, V.G., Malanchuk, Z.R, \& Malanchuk Ye.Z. (2016). Revisiting the underground gasification of coal reserves from contiguous seams. Naukovyi Visnyk Natsionalnoho Hirnychoho Universytetu, (6), 60-66.

12. Blinderman, M.S., \& Klimenko, A.Y. (2018). Introduction to underground coal gasification and combustion. Underground Coal Gasification and Combustion, 1-8. https://doi.org/10.1016/b978-0-08-100313-8.00001-3

13. Klimenko, A.Y. (2018). Early developments and inventions in underground coal gasification. Underground Coal Gasification and Combustion, 11-24. https://doi.org/10.1016/b978-0-08-100313-8.00002-5

14. Otto, C., \& Kempka, T. (2020). Synthesis Gas Composition Prediction for Underground Coal Gasification Using a Thermochemical Equilibrium Modeling Approach. Energies, 13(5), 1171. https://doi.org/10.3390/en13051171

15. Rosen, M.A., Reddy, B.V., \& Self, S.J. (2018). Underground coal gasification (UCG) modeling and analysis. Underground Coal Gasification and Combustion, 329-362. https://doi.org/10.1016/b978-0-08-100313-8.00011-6

16. Sutardi, T., Paul, M.C., \& Karimi, N. (2019). Investigation of coal particle gasification processes with application leading to underground coal gasification. Fuel, (237), 1186-1202. https://doi.org/10.1016/i.fuel.2018.10.058

17. Bondarenko, V., Lozynskyi, V., Sai, K., \& Anikushyna, K. (2015). An overview and prospectives of practical application of the biomass gasification technology in Ukraine. New Developments in Mining Engineering 2015: Theoretical and Practical Solutions of Mineral Resources Mining, 27-32. https://doi.org/10.1201/b19901-6

18. Dychkovskyi, R., Avdiushchenko, A., \& Lozynskyi, V. (2017). Some Economic Indicators of Coal Mining from Thin Seams. Advanced Engineering Forum, 22, 13-20. https://doi.org/10.4028/www.scientific.net/aef.22.13

19. Lozynskyi, V.H., Dychkovskyi, R.O., Falshtynskyi, V.S., \& Saik, P.B. (2015). Revisiting possibility to cross disjunctive geological faults by underground gasifier. Naukovyi Visnyk Natsionalnoho Hirnychoho Universytetu, (4), 22-27. 
20. Saik, P., Petlevanyi, M., Lozynskyi, V., Sai, K., \& Merzlikin, A. (2018). Innovative approach to the integrated use of energy resources of underground coal gasification. Solid State Phenomena, (277), 221-231. https://doi.org/10.4028/www.scientific.net/SSP.277.221

21. Tabachenko, M. (2016). Features of setting up a complex, combined and zero-waste gasifier plant. Mining of Mineral Deposits, 10(3), 37-45. http://dx.doi.org/10.15407/mining10.03.037

22. Falshtynskyi, V., Saik, P., Lozynskyi, V., Dychkovskyi, R., \& Petlovanyi, M. (2018). Innovative aspects of underground coal gasification technology in mine conditions. Mining of Mineral Deposits, 12(2), 68-75. https://doi.org/10.15407/mining12.02.068

23. Falshtyns'kyy, V., Dychkovs'kyy, R., Lozyns'kyy, V., \& Saik, P. (2013). Justification of the gasification channel length in underground gas generator. Mining of Mineral Deposits, 125-132. https://doi.org/10.1201/b16354-23

24. Falshtynskyi, V., Dychkovskyi, R., Lozynskyi, V., \& Saik, P. (2015). Analytical, laboratory and bench test researches of underground coal gasification technology in National Mining University. New Developments in Mining Engineering 2015: Theoretical and Practical Solutions of Mineral Resources Mining, 97-106. https://doi.org/10.1201/b19901-19

25. Falshtynskyi, V.S., Dychkovskyi, R.O., Lozynskyi, V.G., \& Saik, P.B. Some aspects of technological processes control of an in-situ gasifier during coal seam gasification. Progressive technologies of coal, coalbed methane, and ores mining, 109-112. https://doi.org/doi:10.1201/b17547-20

26. Falsztinskij, W., Diczkowskij, E., \& Lozinskij, W. (2010). Ekonomiczne uzasadnienie celowości doszczelniania skał stropowych nad obszarem podziemnego zgazowania węgla metodą otworów wiertniczych. Prace Naukowe GIG. Górnictwo i Środowisko/Główny Instytut Górnictwa, (3), 51-59.

27. Dychkovskyi, R.O., Lozynskyi, V.H., Saik, P.B., Petlovanyi, M.V., Malanchuk, Ye.Z., \& Malanchuk, Z.R. (2018). Modeling of the disjunctive geological fault influence on the exploitation wells stability during underground coal gasification. Archives of Civil and Mechanical Engineering, 18(4), 1183-1197. https://doi.org/10.1016/j.acme.2018.01.012

28. Lozynskyi, V., Saik, P., Petlovanyi, M., Sai, K., Malanchuk Z., \& Malanchyk, Ye. (2018). Substantiation into mass and heat balance for underground coal gasification in faulting zones. Inzynieria Mineralna, 19(2), 289-300. http://doi.org/10.29227/IM-2018-02-36

29. Falshtynskyi, V.S., Dychkovskyi, R.O., Lozynskyi, V.G., \& Saik, P.B. (2013). Determination of the Technological Parameters of Borehole Underground Coal Gasification for Thin Coal Seams. Journal of Sustainable Mining, 12(3), 8-16. https://doi.org/10.7424/jsm130302 